\title{
THE CONCEPT OF UNIVERSAL HUMANITY OF PANCASILA BASED ON AL-QUR'AN
}

\author{
Akmal Rizki Gunawan Hasibuan1 \\ Islamic University 45 of Bekasi, Indonesia \\ (Email: akmalgunawangulen@gmail.com) \\ Rabiyannur Lubis ${ }^{2}$ \\ Islamic University 45 of Bekasi, Indonesia \\ (Email: r4biyannurlubis@gmail.com) \\ Abdul Khoir ${ }^{3}$ \\ Islamic University 45 of Bekasi, Indonesia \\ (Email: Juragankhoir2@gmail.com)
}

Accepted date: $23-04-2019$

Published date: 11-07-2019

To cite this document: Hasibuan, A. R. G., Lubis, R., \& Khoir, A. (2019). The Concept of Universal Humanitiy of Pancasila Based on Al- Qur'an. International Journal of Humanities, Philosophy, and Language, 2(6), 179-186.

DOI: $10.35631 / \mathrm{ijhpl} .260015$

Abstract: This is important to do research of the concepts that offered by Pancasila. Look at about global politics today imposes a variety of ways to achieve the goals, which lead to radicalism and terrorism. Interestingly, the stigma is by the western, the proportion is more closely compared with the Islamic movement, since the incident of 9/11. The data collected from 80 articles, journals and books. The data that were analyzed Madhui al-Farmawi's theory. The results of this discuss study that the concept of the universal concept of Pancasila based on Al-Quran carrying on the interconnection and harmonious interaction between humans and Allah (habl maa Allah), humans with themselves (habl maa nafsih), and humans with others (habl maa-nas).

Keywords: The Universal of Humanity, Pancasila, Al-Quran

\section{Introduction}

Conscious or not, nowadays the world's political conditions after the incident of 9/11 bring up a suspicion towards the humanitarian movement of Islam by the Western world. The problems of humanitarian principles in Islam is often to compare with religious missions and the symptoms of Islamic radicalism. So, that humanitarian activities by Islamic institutions still get a bad image from the non-Islamic world.

\footnotetext{
${ }^{1}$ Faculty Islamic Education, Islamic University “45” of Bekasi, Indonesia, (akmalgunawangulen@ gmail.com). ${ }^{2}$ Faculty Islamic Education, Islamic University “45” of Bekasi, Indonesia, (r4biyannurlubis@ gmail.com.). ${ }^{3}$ Faculty Islamic Education, Islamic University “45” of Bekasi, Indonesia, (Juragankhoir2@gmail.com).
} 
The mutual suspicion between the Islamic world and the Western is indeed unavoidable even when we discuss the management of the humanitarian movement. As understood, the concept of modern humanity has been formulated through a very long process in Western countries. When referring to the history of the development of the international humanitarian movement in the Western world, the concept formulations are more "secular", as formulation in the Geneva Conventions on the Protection of Victims of Conflict which tend to separate the primordial characteristics of modern humanitarian practices. That phenomenon which for a dozen years has become a debate among humanitarian activists. That is, not all circles agree with the formulation of humanitarian ideologies that break away from identity or religious symbols. Because, precisely religious ethics has become its own inspiration for adherents to be more active in humanitarian activities, such as providing assistance to disaster victims, both at the disaster site and at the location of the conflict. ${ }^{4}$

Clearly, the Western "liberal" and "secular" approach to humanitarian issues is not entirely acceptable to Muslim society. Moreover, Western domination in global politics has exacerbated the relationship between the Islamic world and the West and seems to justify the occurrence of clashes between these two great civilizations. In the complexity of the relationship between Islam and the West this is the meaning of humanitarianism is often debated. Humanization means humanizing humans, eliminating "material", dependence, violence and hatred from humans. Humanization is in accordance with the spirit of Western liberalism. It just needs to be added immediately, if Western civilization is born and rests on anthropocentric humanism, the concept of Islamic humanism is rooted in theocentric humanism. Therefore, humanization cannot be fully understood without understanding the concept of transcendence that become the basis.

Western humanism was born from a revolt against dogmatic Church authority in the Middle Ages. An anthropocentric view assumes that life is not God-centered but in humans. The ethos is the spirit of respecting the values built by man himself. The anthropocentric civilization makes humans the benchmarks of truth and falsehood, to use humans as a criterion of beauty and to give importance to parts of life that promise human power and pleasure. Antropocentrism considers man as the center of the world, and therefore feels enough with himself. An anthropocentric man feels to be a ruler for himself. Not only that, he also went further, he want to be a ruler for others. The universe then became the target of powerful lust which became increasingly uncontrollable. ${ }^{5}$

With the ratios as a weapon, anthropocentric humans begin the history of power and exploitation of nature without limits. Modernism with the banner of rationalism has been proved to cause natural damage unspeakable to nature and humans. Science is war whose methods and tactics of war have been written very intelligently by Descartes through his motto "Cogito Ergo Sum". Through Descartes' warfare, modern civilization created war machines against nature in the form of sophisticated technology to conquer and exploit infinite nature, as well as machines of war against humans in the form of sophisticated supermodern weapons, bombs, and even weapons of mass destruction. So, instead of

${ }^{4}$ Hilman Latief \& Zezen Zaenal Mutaqin, Islam dan Urusan Kemanusiaan: Konflik, Perdamaian, dan Filantropi, (Jakarta: PT. Serambi Ilmu Semesta, 2015), 25.

${ }^{5}$ Kuntowijoyo, Paradigma Islam: Interpretasi untuk Aksi, (Bandung:

Mizan, 1994), 264-271. 
anthropocentric humanism it succeeded in carrying out the process of humanization, what actually happened was a process of dehumanization.

Islam then proposes theocentric humanism instead of anthropocentric humanism to revive human dignity. With this concept, humans must focus on God, but the goal is for the benefit of humans (humanity) themselves. The development of human civilization is no longer measured by rationality but transcendence. Humanization is needed because the community is in a three acute conditions named dehumanization (technological activation, economics, culture and state), aggressiveness (collective aggressiveness and crime) and loneliness (privatization, individuation).

At present, humanitarian discourse and practice are not only formed and formulated by the international community which are active in disaster relief activities, but also by new players who have different political and religious backgrounds and tendencies. Among Muslims themselves, the presence of Islamic humanitarian organizations is very important in the formation of ideas and principles of "universal humanity" in the future.

Why Islam is important? Today, Islam is the second largest religion in the world after Christianity and more than one billion Muslims with diverse cultures and traditions, living in various parts of the world. However, until now, some little effort has been made to develop humanitarian principles of Islam or more specifically formulate "Islamic humanitarian law" which can serve as a general guide for Muslims throughout the world in carrying out agendas and humanitarian activities, especially in conflict locations.

\section{Discourse on the Transformation of Social Humanity}

Debates about the methodology and approaches of the social sciences are constantly evolving. At first the social sciences approach was dominated by positivistic approaches, which were based more on pure science. The positivistic approach as we know it was introduced by Modern sociologist, August Comte. However, when many problems arise in the human community (human community) that cannot be understood with positivistic rules or pure science and sich. So people then wondered whether the approach to solving natural and social phenomena must continue over time. It was thereafter, experts in the social field then formulated a relatively new approach, namely the hermeneutic approach that was closer to the approach of reality that occurred in society. This approach was popularized by sociologists-sociologists Emile Durkheim, Max Weber, Hegel and Edmund Husserl. ${ }^{6}$

Meanwhile, after the hermeneutic approach, a critical approach was developed, which became known in the tradition of social sciences with a critical sociology approach which was more likely to see social phenomena in a multi-interpretive, deconstructive way because social phenomena in society were not a single phenomenon and could be understood monodisciplinary. The initiators and at the same time the main experts in the field of social science or critical sociology include, Max Horkheimer, Walter Benjamin, Herbert Marcuse,

\footnotetext{
${ }^{6}$ Zuly Qodir, "Pendekatan Integralistik: Sosiologi Untuk Kajian Islam dan Sosial", Jurnal Sosiologi Reflektif, Volume 8, No. 1, Oktober (2013), 26.
} 
Jurgen Habermas, and Theodore Adorno, who were the founders of the Frankfurt school. This school is known for the school they developed, the Frankfurt School in. ${ }^{7}$

While in the Islamic world there were also several figures, both with Western and Middle Eastern educational backgrounds, including, M. Arkoun, Hassan Hanafi, Fazlur Rahman, besides that, also in Indonesia a number of figures emerged such as Nurcholish Madjid, Buya Syafi'i, and Kuntowijoyo, and many others. Those who try to talk about Islam and social change, according to them, because Islam always attracts attention, because of the fact that there is a close relationship between the two, both in Islamic history in general and the development of Indonesian Islam. Islam is not only a rigid formal order of worship against the social-community reality, Islam as a system of values that is quite comprehensive is certainly very sensitive to the actual reality as a form of actualization to-Rahmatan lil amin alaminnya. Therefore, for human society in general and those who already have trust in God. Also, besides that, Islam in its history appears as an ahistory and asociology.

In the historical reality, the struggle to obtain and maintain human dignity is a dominant feature of the life experience of humans as social beings. In radical historicalization, and constantly in the process of change and transformation, individuals themselves are composed of many identities, and the diversity of these individual identities is constructed in different contexts. In the process of transformation and construction, Islamic discursive practices play a decisive role. ${ }^{8}$

See the above phenomenon, the question is: why is the magnitude of the struggle that continues to happen? And for Muslims, especially in Indonesia, how exactly the concept of humanity has to offer?

\section{Humanity of Pancasila Based on Al-Quran}

It must be admitted that the humanitarian character of the Indonesian people is rooted through the ideology of the Pancasila. Save the author, the values contained in it are very relevant to the context of Indonesianness and Islam. Therefore, this study seeks to formulate and harmonize these values with the verses of the Koran. Where, in this case the author seeks to establish this understanding through an in-depth analysis of al-Azhar's interpretation of Buya Hamka.

As for this fair and civilized humanitarian principle, Hamka explained that we must learn about our responsibility towards humans in the view of Islam. Because humans are the subject and core in the second precept. In this case Hamka associates Q.S. al-Baqarah [2]: 30. Allah ta'ala He said:

"And [mention, O Muhammad], when your Lord said to the angels, "Indeed, I will make upon the earth a successive authority." They said, "Will You place upon it one who causes corruption therein and sheds blood, while we declare Your praise and sanctify You?" Allah said, "Indeed, I know that which you do not know." (Q.S. al-Baqarah [2]:30).

\footnotetext{
${ }^{7}$ Zuly Qodir, "Pendekatan Integralistik: Sosiologi Untuk Kajian Islam dan Sosial”, Jurnal Sosiologi Reflektif, Volume 8, No. 1, Oktober (2013), 26-27. Lihat juga dalam Andy Dermawan, "Dialektika Teori Kritis Mazhab Frankfurt dan Sosiologi Pengetahuan”, Sosiologi Reflektif, Volume 8, No. 1, Oktober (2013), 251.

${ }^{8}$ Nurcholish Madjid, Islam Doktrin dan Peradaban (Paramadina: Jakarta, 2008), 116.
} 
Hamka in this context interprets, "That God revealed His intention to His angels that He wanted to appoint His caliph Adam as the first human to be made caliph. The Caliph is the person who is entrusted with the responsibility to continue the will of those who caliph him. The angel expressed his consideration, according to the curve of the calculation, that the caliph would be appointed by Allah might bring damage to the earth and shed blood because he happened from flesh and blood, which became a nest of life. While angels don't do that. They are created from nur (light) that does not grow and they are able to say the prayer to praise Allah and purify Him. However, Allah answers that He knows more about what they do not know. That is, what is seen by angels is only damage and shedding of blood. That indeed, but behind the damage and shedding of blood later humans will find their own way of life. From there it will open the secrets of the earth and nature that God gave them to think about. Indeed, thousands of years have lived in the world, indeed blood has been spilled and indeed damage has occurred repeatedly. However, angels cannot deny the progress of life and humanity and prove the existence of high power in nature. Humans are increasingly advancing and some names have been shown to Adam. Hidden secrets have been dismantled by the human mind. "Kuntu Kanzan Makhfiyah" is a hidden treasury. So humans are a day, a year, a hundred thousand years, who dismantle this treasury ". 9

This interpretation confirms that based on Adam's events and the responsibility that was borne by him, there appeared religious unity, the unity of humanity under the unity of God. Explained again in the word of God that humans are one people. And God said:

"Mankind was one, then Allah sent prophets bringing good news and warnings, and He sent down with them the Book with truth" (Q.S. al-Baqarah [2]: 213).

In Q.S. al-Baqarah [2]: 213 This is Hamka explaining, That the base of this verse is one of the foundations of sociology that is instilled by Islam, to be stretched long by a mind that is intelligent and willing to investigate. Where the whole human being is essentially one people. That is, even though the color of the skin is different, different languages are used, dwell in various worlds and islands, but in their humanity they are one. ${ }^{10}$

Indeed at the end of verse Q.S. al-Baqarah [2]: 213 it also explained the occurrence of disputes and disputes is after the book came because of mere neglect. However, God gives His guidance to those who believe so that they are free from conflict because they want the truth. So, it is very heavy and very human burden when he is blessed to live in this world. They are all seen as one and the same bear responsibility, want to perfect God's will on earth. They are all God's caliphs on earth. The human burden of being a khalifatullah is also strengthened in another verse, al-An-:am: $165 .^{11}$

Hamka added, that in Faatir surah verse 39, surah al-A'raaf verses 68 and 73, in surah anNaml verse 62, and in surah Yunus verse 14, it can be proved to be related and strongstrengthen among the verses that humans all of them are the caliphs of Allah. Therefore, wanting to bear that responsibility, God sent apostles and prophets with several books. Islam

\footnotetext{
${ }^{9}$ Hamka, Keadilan Sosial dalam Islam (Jakarta: Gema Insani, 2015), 18.

${ }^{10}$ Hamka, Tafsir Al-Azhar Juz, II, 218.

${ }^{11}$ Artinya: "Dan dialah yang menjadikan kamu sebagai khalifah-khalifah di bumi dan Dia mengangkat (derajat) sebagian kamu di atas yang lain, untuk mengujimu atas (karunia) yang diberikan-Nya kepadamu. Sesungguhnya Tuhanmu sangat cepat memberi hukuman dan sungguh, Dia Maha pengampun, Maha penyayang".
} 
teaches that the content of the purpose of the coming of the prophets is one, namely guiding humanity so that he can pay his heavy and noble obligations. The secret of the arrival of the prophets and apostles is one and Muhammad is the end of the apostles to fulfill the dead that was abandoned by the apostles and prophets first. Because it was raised by humanity with a direct relationship to al-Khaliq. There is no one who can take a special place to demean other humans. Only a joint effort to make yourself closer to God. With the teachings of Islam refuted the basis of the old government of humans in establishing the state and society, namely looking at the king, grandmother, or dukun as God. Therefore, Islam recommends that people try to always take the fragments of the nature of God "Ittasifu bi divine nature". Be characteristic of the nature of Allah, not ordain a human, purify it and others are willing to be slaves and obey what they regulate, and he should not be blamed and be seen as innocent. In this case, the Prophet also affirmed:

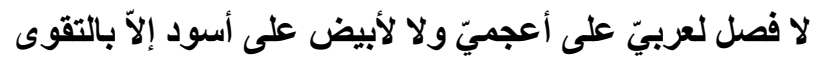

"There is no excess of the Arab nation of the Ajam (non-Arabs) and there is no excess of white people over black people, but because of their taqwa (Muslim History)".

\section{خير الناس من أنفعه للناس}

"As good as possible, humans are the ones who benefit the most from fellow humans" (Jabir's History).

As for those who are religious, it says: "There is no compulsion in religion". ${ }^{12}$

Hold on to the rope of all God, do not divide. Even though they are of different religions, have different beliefs, have different parties, but the people who believe in the One and Only God, do not differ in their call to what Bung Karno always calls out, "let's unite". Let's unite in trusting God. ${ }^{13}$ As Hamka's statement regarding Q.S. Ali-Imran [3]: 64. ${ }^{14}$

From the explanation above, Hamka concludes, "Isn't it here that the dictator's spirit is strongly resisted, the spirit of deifying the leader, and only one purpose, namely the One Godhead? Seeing the humanity that arises from the One Precepts of Godhead, lies with his belief in the One Godhead, if he is not a theory of humanity which honesty can guarantee, as long as it is not based on the One. ${ }^{15}$

"Then please the second Pancasila is very appropriate for us to explore its meaning: "Just and civilized humanity" In the sense that we respect others as human beings by means of humanizing our humanity by being just and civilized. This is the ethical foundation of association that has been outlined in the second principle of the Pancasila. I am human, and you are human, let us be just and civilized. Combine three key words (humanity, just and

\footnotetext{
${ }^{12}$ Q.S. al-Baqarah: 256.

${ }^{13}$ Hamka, Nasir, Muzakkir, Anshary, Singodimedji, Debat Dasar Negara Islam dan Pancasila Konstituante 1957: Urat Tungang Pancasila, 152.

14 "O People of the Scripture, come to a word that is equitable between us and you - that we will not worship except Allah and not associate anything with Him and not take one another as lords instead of Allah." But if they turn away, then say, "Bear witness that we are Muslims [submitting to Him]".

${ }^{15}$ Hamka, Nasir, Muzakkir, Anshary, Singodimedji, Debat Dasar Negara Islam dan Pancasila Konstituante 1957: Urat Tungang Pancasila, 153.
} 
civilized), because this is the noble value of our nation and in accordance with all the teachings of our religions in Indonesia. ${ }^{16}$

\section{Conclusion}

Based on the analysis of research results using qualitative research methods and library research approaches (library research), it can be concluded as follows:

1). It becomes clear that one of the urgencies of why Muslims today need a formulation of Islamic social theory is that Muslims and even humans in general are able to actualize their faith in objective reality, so that it can be a manifestation of pious deeds effectively in conditions and social realities humanitarian objective.

2). With the research library approach to the related literature, this study concludes that the Koranic concept of universal humanity based on the Qur'an carries the theocentric humanist theory. This is based on the Koran's description of the interconnection and harmonious interaction between humans and Allah ( habl ma'a Allah), human beings with themselves (habl ma'a nafsih) human beings and the others (habl ma 'al-nas).

\section{References}

Abdurrahman, Moeslim, Islam Sebagai Kritik Sosial, Jakarta: Erlangga, 2003.

Anwar, M. Syafi'i, Pemikiran dan Aksi Islam Indonesia: Sebuah Kajian Politik Tentang Cendekiawan Muslim Orde Baru, Jakarta: Paramadina, 1999.

Assyaukanie, Luthfi, Ideologi Islam dan Utopia: Tiga Model Negara Demokrasi di Indonesia, Freedom Institute: Jakarta, 2011.

Dermawan, Andy. "Dialektika Teori Kritis Mazhab Frankfurt dan Sosiologi Pengetahuan" Sosiologi Reflektif, Volume 8, No. 1, Oktober 2013.

Fauzie, Nurdin, dkk, Transformasi Keagamaan, Fakultas Ushuluddin: Bandar Lampung, 2001.

Hamka, Tafsir Al-Azhar. Jakarta: PT Pustaka Panjimas, 2004.

Hamka, dalam Rusjdi (ed.), StudiIslam: Revolusi Ideologi dan Keadilan Sosial. Jakarta: PT Pustaka Panjimas, 1984.

Hamka, Nasir, Muzakkir, Anshary, Singodimedji, Debat Dasar Negara Islam dan Pancasila Konstituante 1957: Urat Tungang Pancasila. Jakarta: Pustaka Panji Mas, 2001.

Hamka, Dari Hati ke Hati. Jakarta: Gema Insani Press, Cet I, 2016.

Hardiman, F. Budi, Kritik Ideologi, Pertautan Pengetahuan dan Kepentingan, Cet. 2 Yogyakarta: Kanisius, 1990.

Husnul Muttaqin, "Menuju Sosiologi Profetik" Jurnal Sosiologi Reflektif, Volume 7, Nomor 1, Oktober 2012.

Madjid, Nurcholish, Islam Doktrin dan Peradaban, Paramadina: Jakarta, 2008.

Maarif, Ahmad Syafi'i, Islam dalam Bingkai ke-Indonesia-an dan kemanusiaan, Bandung: Mizan, 2015.

Mulkhan, Abdul Munir, Jejak Pembaruan Sosial dan Kemanusiaan Kiai Ahmad Dahlan, Jakarta: PT. Kompas Media Nusantara, 2010

Latif, Yudi, Inteligensia Muslim dan Kuasa: Genealogi Inteligensia Muslim Indonesia Abad ke 20 , Mizan: Bandung, 2012.

\footnotetext{
${ }^{16}$ Hamka, Nasir, Muzakkir, Anshary, Singodimedji, Debat Dasar Negara Islam dan Pancasila Konstituante 1957: Urat Tungang Pancasila, 153.
} 
Jurdi, Syarifuddin, Pemikiran Politik Islam Indonesia: Pertautan Negara, Khilafah, Masyarakat Madani, dan Demokrasi, Yogyakarta: Pustaka Pelajar, 2008

Kuntowijoyo, Paradigma Islam: Interpretasi untuk Aksi, Bandung: Mizan, 1994.

Rachman, Budhy Munawar, (penyunting), Ensiklopedi Nurcholish Madjid: Pemikiran Islam di Kanvas Peradaban. Vol. I. Paramadina: Jakarta, 2011.

Priyono, A.E., "Periferilisasi, oposisi, dan Integrasi Islam di Indonesia (Menyimak Pemikiran Dr. Kuntowijoyo) pengantar dalam Kuntowijoyo, Paradigma Islam: Interprtasi Untuk Aksi, Mizan: Bandung, 1998.

Qodir, Zuly. "Pendekatan Integralistik: Sosiologi Untuk Kajian Islam dan Sosial" Jurnal Sosiologi Reflektif, Volume 8, No. 1, Oktober 2013.

Syihab, Quraish M. Wawasan al-Qur'a>n: Tafsir Maudhu'i atas Berbagai Permasalahan Umat. Bandung: Mizan: 1997.

Syihab, Quraish M. Tafsir al-Misbah: Pesan, Kesan, dan Keserasian al-Quran Vol. 1. Jakarta: Lentera Hati, 2002.

\begin{tabular}{c}
,------- Dari Lembah Cita-Cita (Jakarta: Bulan Bintang, 1982. \\
\hline
\end{tabular}

— IslamTransformatif, Jakarta: Pustaka Firdaus, 1999

—, Islam Yang Memihak, Yogyakart: LkiS, 2005.

—, Islam Sebagai Ilmu: Epistemologi, Metodologi, dan Etika, Yagyakarta: Tiara Ilmu, 2006.

---------, Irfan. Ayah. Jakarta: Republika, 2013.

---------, Keadilan Sosial dalam Islam. Jakarta: Gema Insani, 2015.

--------, Kenang-kenangan Hidup. J. 1. Jakarta: Bulan Bintang, 1979.

--------, Kenang-kenangan Hidup. J. 2. Jakarta: Bulan Bintang, 1979).

- Muslim Tanpa Masjid, Bandung: Mizan, 2001

---------, Pribadi Hebat. Jakarta: Gema Insani, 2014.

--------, Tafsir Al-Azhar.Jakarta: Pustaka Panjimas, 2008.

---------, Tafsir Al-Azhar. Jakarta: Pustaka Panjimas, 1982.

--------, Tafsir Al-Azhar. Singapura: Pustaka Nasional Pte Ltd, cet. 4, 2001.

--------, Tasawuf Modern. Jakarta: Pustaka Panjimas,1987.

- Tradisi Islam: Peran dan Fungsinya Dalam Pembangunan di Indonesia, Paramadina: Jakarta, 2008.

-,Umat Islam Menghadapi Tangan Kristenisasi dan Sekulerisasi. Jakarta: Pustaka Panjimas, 2003. 